\title{
Contribution of liquid fertilizers to improve productivity of late sown wheat in western plain zone of Uttar Pradesh
}

\author{
SANJEEV KUMAR, A.K. KATIYAR* AND ANUJ KUMAR \\ Krishi Vigyan Kendra, Beghra, MUZAFFARNAGAR (U.P.) INDIA (Email : katiyarakpbt@ gmail.com)
}

\begin{abstract}
The field experiments were conducted in Muzaffarnagar districtof Uttar Pradesh in winter of 2011-12 and 2012-13 to estimate the effect of liquid applied nutrients on the yield of late sown wheat at ten farmer's fields. The wheat variety PBW-373 was grown in both the year experiments. Soil of the experimental site was physico-chemically analyzed before sowing of experiments. Nutrient solution were prepared for liquid application as one per cent sulphur solution prepared from 80 per cent W.P. sulphur, 1 per cent iron solution prepared from 19 per cent ferrous sulphate, 0.5 per cent zinc solution prepared from 21 per cent zinc sulphate and 0.5 per cent manganese solution prepared from 30.5 per cent manganese sulphate commercially available from the market. These solutions were sprayed on standing crop at tillering and boot stage (30 and 60 days after sowing). All the liquid applications were in addition of farmer used fertilizer. Farmers in Muzaffarnagar district generally using NPK 145:80:40, as 5 bag NPK (12:32:16) and 5 bag of urea $(46 \% \mathrm{~N})$ in one hectare of wheat production. The maximum grain yield (41.4 $\mathrm{q} /$ ha) was recorded from zinc application and lowest ( $39.0 \mathrm{q} / \mathrm{ha}$ ) from control treatment. Grain yield $40.08 \mathrm{q} /$ ha had been obtained from sulphur application and 39.6q/ ha from iron 40.3q/ ha application and 39.6q/ ha from manganese treatment in Rabi 2011-12. It was also noted that zinc application was significantly increased yield over control.The maximum yield (39.6 q/ ha) was observed from zinc application followed by sulphur application (39.2 q/ ha) which was significant over control treatment in Rabi 2012-13. Lowest yield (38.0 q/ ha) was found from control treatment, $38.5 \mathrm{q} /$ ha from iron application and 37.8 from manganese treatment. Straw yield $50.1 \mathrm{q} /$ ha recorded from zinc application, followed by sulphur ( $49.6 \mathrm{q} / \mathrm{ha}$ ), iron ( $48.6 \mathrm{q} / \mathrm{ha}$ ) and $48.1 \mathrm{q} /$ ha from manganese treatment. It was observed that number of tillers, grain and straw yield were significantly increased over control fromliquid application zinc both the year of experiments.
\end{abstract}

Key Words : Liquid fertilizer, Sulphur, Iron, Zinc, Manganese, Wheat

View Point Article : Kumar, Sanjeev, Katiyar, A.K. and Kumar, Anuj (2015). Contribution of liquid fertilizers to improve productivity of late sown wheat in western plain zone of Uttar Pradesh. Internat. J. agric. Sci., 11 (1): 161-165.

Article History : Received : 07.11.2014; Revised : 01.12.2014; Accepted : 15.12.2014 